\title{
Malnütrisyonlu Çocukların Serbest Plazma Aminoasit Profili ve mTOR Protein Düzeyinin Araştırılması
}

\section{An Analysis of Free Plasma Amino Acid Profile and mTOR Protein Level in Children with Malnutrition}

\author{
Ahmet GÜZELÇiÇEK ${ }^{1}{ }^{(D)}$, Muhammed ŞEYHANLI ${ }^{1}$, Ataman GÖNEL ${ }^{2}{ }^{(D)}$, \\ İsmail KOYUNCU $2 \mathbb{D}$, Hüseyin GÜMÜŞ ${ }^{1} \mathbb{D}$, Doğan KÖSE ${ }^{3} \mathbb{P}$
}

\begin{abstract}
1 Harran Üniversitesi Tıp Fakültesi, Çocuk Sağlığı ve Hastalıkları A.B.D., Şanlıurfa, Türkiye
2 Harran Üniversitesi Tıp Fakültesi, Tıbbi Biyokimya A.B.D., Şanlıurfa, Türkiye

3 Harran Üniversitesi Tıp Fakültesi, Çocuk Hematoloji ve Onkoloji AD, Şanlıurfa, Türkiye
\end{abstract}

Öz.

Amaç: Malnütrisyon bir ya da daha fazla besin öğesinin vücut dengesini bozacak şekilde yetersiz alınması sonucunda ortaya çıkan klinik bir tablodur. Etiyopatogenezin de beslenme problemleri, protein ve enerji eksikliği ve özellikle mammalian target of rapamycin (mTOR) proteini ve kan aminoasitleri ile ilgili eksiklikler mevcuttur. Bu çalışmada büyüme ve gelişme geriliği olan çocukların serbest plazma aminoasit profili ve mTOR protein düzeyinin araştırımasını amaçladık.

Materyal ve metod: Çalışmamızda hastanemiz pediatri polikliniğine başvuran 0-18 yaş arasında boy ve kilosu üç persantilin altında olan malnütrisyonlu 48 çocuk ve 47 sağ|ıklı kontrol arasında mTOR ve kan aminoasit düzeyleri karşılaşıtıııldı

Bulgular: Beslenmenin yetersizliğine bağlı olarak malnütrisyon olan çocuklarda mTOR ve aminoasit seviyelerinde düşüklük beklenmesine rağmen kontrol grubu ile hasta grubu arasında anlamlı fark bulunamadı. Sonuç: Büyüme ve gelişme geriliği olan çocuklarda bakılan mTOR ve aminoasit profili özel bir belirteç olarak kullanılamasa da bu alanda yapılacak birçok çalışmaya ışık tutabileceği kanısına varıldı.

Anahtar Kelimeler: Malnütrisyon, Beslenme, Aminoasit, mTOR

\section{Abstract}

Background: Malnutrition is a clinical case that stems from inadequate intake of one or more nutritional elements and results in an imbalance within the body. In its etiopathogenesis, feeding problems, protein and energy deficiency and particularly insufficiency of mTOR protein and blood amino acids are listed. In this study, we aimed to examine free plasma amino-acid profile and mTOR protein level in children with growth and developmental delay.

Materials and Methods: In our study, mTOR and blood amino acid levels were compared among 48 malnourished children aged 0-18 years who were admitted to our hospital's pediatric outpatient clinic and whose height and weight were below the three percentile and 47 healthy controls.

Results: The study were included 48 patients and 47 healthy children. Although mTOR and aminoacid levels were expected to be low in malnourished children, there was no significant difference between the control and patient groups.

Conclusion: Even though mTOR level and amino-acid profile, which are checked in children with growth and developmental delay, are not considered to be particular indicators, it is concluded that they can illuminate the pathway for further studies in this field.

Key words: Malnutrition, Nutrition, Amino acid, mTOR

\section{Sorumlu Yazar I \\ Corresponding Author}

\section{Dr. Ahmet GÜZELÇIÇEK}

Harran Üniversitesi, Tıp Fakültesi

Çocuk Sağlığı ve Hastalıkları AD.,

Osmanbey Kampüsü 63300 Haliliye

Şanliurfa

Tel: +90 (0414) 3444444

$$
\text { +905529472003 }
$$

Fax:+90 (414) 3183209

e-mail: aguzelcicek@harran.edu.tr tel:

Geliş tarihi / Received: 09.07.2020

Kabul tarihi / Accepted: 19.08.2020

DOI: 10.35440/hutfd.767424 


\section{Giriş}

Malnütrisyon bir ya da daha fazla besin öğesinin vücut dengesini bozacak şekilde yetersiz alınması sonucunda ortaya çıkan klinik bir tablodur (1).

Protein-enerji malnütrisyonu (PEM) dünya nüfusunun büyük çoğunluğunu oluşturan gelişmekte olan ve az gelişmiş ülkelerde en önemli sağlık problemlerinden biridir; çocuklarda artmış mortalite ve morbidite ile ilişkilidir (2). PEM temelinde kronik hastalıklar yanında, ondan daha önemli olan, hızlı nüfus artışı, mevcut besin kaynaklarının toplumda eşit dağılımının olmayışı, gelir düzeyi düşüklüğü, yanlış beslenme alışkanlıkları gibi sosyal problemler de yatmaktadır (3). Çocuklardaki beslenme problemleri nedeniyle meydana gelen gelişim geriliğine bazen protein ve enerji eksikliği de eşlik edebilir. Çocuğun yaşına, diyette enerjiye oranla proteinin miktar ve niteliğine, eksikliğin süresine ve derecesine göre birbirinden farklı klinik tablolar ortaya çıkar. Çocuklarda büyüme ve gelişmenin hızı olması sebebiyle gereksinimin arttı̆ı dönemlerde, enfeksiyon atakları ile kayıpların arttığı etkisi daha çok görülmektedir (4).

Memeli rapamisin hedefi (mammalian target of rapamycin; mTOR), bir serin treonin kinaz olup hücre büyüme ve çoğalmasının düzenlenmesinde rol oynar (5). Besin varlığında, TOR kinaz aktif hale gelir ve hücre büyümesine yol açan, hücre döngüsünün $\mathrm{G} 1$ 'den $S$ fazına geçmesini kontrol eden proteinlerin translasyonunun başlamasına neden olan mekanizmaların aktif hale gelmesini sağlar (6).

Çalışmamızda büyüme ve gelişme geriliği olan çocuklarda plazma serbest aminoasit düzeyi ve mTOR protein düzeyini inceleyerek, büyüme ve gelişme geriliğinin tanısı ve takibinde kullanılıp kullanılamayacağını saptamayı amaçladık.

\section{Materyal ve Metod}

Hastanemiz pediatri polikliniğine başvuran 0-18 yaştaki boy ve kilo persentil 3'ün altında olan 48 hasta ve yaşları benzer 47 kontrol olmak üzere toplam 95 olgu çalışmaya dahil edildi. Çalışma kontrollü, kesitsel olarak planlandı. Çalışma için etik kurulu onayı alındı (Harran Üniversitesi Tıp Fakültesi Etik Kurulu 09/11/2017 tarih ve 11nolu oturum 04 nolu karar) . Çalışmaya alınan çocukların velilerinden bilgilendirilmiş onam alındı.

\section{LC-MS I MS ile Serumsuz Amino Asitlerin Ölçümü}

Plazma aminoasit miktarı Jasem marka kit protokolüne göre LC-MS/MS ile tespit edildi. Yeni bir tüpe $50 \mu \mathrm{l}$ süpernatant eklenip üzerine $50 \mu$ internal standart karışımı ve $700 \mu \mathrm{l}$ Reaktif-1 ekleyerek 10 saniye vortekslendi.4000 rpm $5 \mathrm{dk}$ santrifüj edildi. Elde edilen supernatan HPLC vialine aktararak LC-MS/MS (Shimadzu 8045, Japan) cihazında 27 aminoasid türü analiz edildi.

mTOR: Çalışılacak olan örnekler (Serum) en az 2 saat öncesinde oda sıcaklığına çıkarıldı. Kit Protokolüne göre aşağıdaki iş şeması uygulandı.

Standart Hazırlama: Liyofilize halde olan standart (10 $\mathrm{ng} / \mathrm{mL}$ stok) 10,000 g'de $1 \mathrm{dk}$ santrifüj edildi ve üzerine $1 \mathrm{ml}$ Reference Sample \& Standard Diluent eklenerek homojenizasyonu sağlandı ve yaklaşık $10 \mathrm{dk}$ bekletildi.

Seri dilüsyon yöntemi ile standartlar hazırlanma: 7 adet temiz tüp yazılarak $(5,2.5,1.25,0.625,0.313,0.156$ $0 \mathrm{ng} / \mathrm{mL}$ ) $300 \mu$ l Reference Sample \& Standard Diluent eklendi. Stok solüsyonunundan $300 \mu \mathrm{l}$ alınarak ilk tüpe aktarıldı ve pipetaj yapılarak bir sonrakine aktarıldı. Bu şekilde (son tüp hariç-blank) son tüpe kadar devam edildi.

Biyotinlenmiş Deteksiyon çalışma solüsyonu hazırlama: Konsantre Biyotin solüsyonu 1: 100 oranında Biyotinlenmiş Seyreltici ile hazırlandı.

Konsantre HRP Konjugat çalışma solüsyonu hazırlama: Konsantre HRP Konjugat 1:100 oranında HRP Konjugat Seyreltici ile hazırlandı.

\section{Çalışma prosedürü}

1. Playte 2 tekrar yıkandı.

2. 96 kuyucuklu playte $100 \mu \mathrm{l}$ standart ve örnek olacak şekilde dikkatlice eklendi. $90 \mathrm{dk} 37^{\circ} \mathrm{C}$ 'de inkübe edildi. Playte 2 tekrar yıkandı.

3. Biyotinlenmiş deteksiyon çalışma solüsyonundan $100 \mu$ leklenerek, yapışkan film ile kaplandı ve $60 \mathrm{dk} 37^{\circ} \mathrm{C}$ 'de inkübe edildi.

4. Tüm kuyucuktaki sıvılar uzaklaştııılı ve yaklaşık $350 \mu$ l olacak şekilde yıkama solüsyonu $(30 \mathrm{ml}$ konsantre wash $+750 \mathrm{ml} \mathrm{d} \mathrm{H}_{2} \mathrm{O}$ ) ile 1-2 dk arayla 3 tekrar yıkandı.

5. $100 \mu \mathrm{l} \mathrm{HRP} \mathrm{Konjugat} \mathrm{çalışma} \mathrm{solüsyonu} \mathrm{eklendi}$ ve $30 \mathrm{dk} 37^{\circ} \mathrm{C}$ 'de inkübe edildi.

6. Tüm kuyucuktaki sıvılar uzaklaşısııılı ve yaklaşık $350 \mu$ lacak şekilde yıkama solüsyonu (30 ml konsantre wash $+750 \mathrm{ml} \mathrm{d} \mathrm{H}_{2} \mathrm{O}$ ) ile 1-2 dk arayla 5 tekrar yıkandı.

7. $90 \mu \mathrm{I} \mathrm{TMB}$ substrat eklenerek $15 \mathrm{dk} 37^{\circ} \mathrm{C}$ 'de inkübe edildi. (karanlık ortamda)

8. $50 \mu \mathrm{l}$ stop solüsyonu eklenerek enzim aktivitesi durduruldu ve optik yoğunluğu (OD) 450nm okutularak tespit edildi.

Assay range: $0.156-10 \mathrm{ng} / \mathrm{ml}$

Sensitivity: $<0.094 \mathrm{ng} / \mathrm{ml}$

\section{İstatistiksel Analizler}

İstatistiksel analizler SPSS for Windows Versiyon 20,0 (Statistical Package for the Social Sciences) bilgisayar programı kullanılarak yapıldı. Değişkenler arasındaki ilişki pearson ve Kendall's korelasyon testleri ile ve gruplar arasındaki fark Student's t-test ile gerçekleştirildi. Nonparametrik test verileri için iki grup arasındaki değerlerin farkına Mann-Whitney U testi ile bakıldı. Sonuçlar \% 95'lik güven aralığında, anlamlılık $p<0,05$ düzeyinde değerlendirildi. 


\section{Bulgular}

Bu çalışmaya malnütrisyonlu 48 hasta ve 47 sağ|ıklı kontrol dahil edildi. Hasta grubunun yaş ortalaması $67.89 \pm 60.52$ ay, kontrol grubunun yaş ortalaması $75.46 \pm 51.85$ ay idi. Hasta grubunun boy ortalamas I $99.08 \pm 31.39 \mathrm{~cm}$, kontrol grubunun boy ortalaması $109.17 \pm 29.82 \mathrm{~cm}$ idi. Hasta grubunun kilo ortalaması $18.33 \pm 15.97 \mathrm{~kg}$, kontrol grubunun kilo ortalaması $19.74 \pm 14.69 \mathrm{~kg}$ idi. Olguların mTOR protein düzeylerine bakıldığında hasta grubunda ortalama $(4,90 \pm 1,90)$ kontrol grubu ortalama $(4.67 \pm 1.51)$ değerine göre daha yüksekti ancak istatistiksel olarak anlamlı değildi $(p=0,558)$.

Olguların amino asit düzeylerine bakıldığında, hasta grubunun Arg düzeyi kontrol grubuna istatistiksel olarak düşük bulundu. Diğer amino asit parametrelerinde istatistiksel olarak anlamlı bir fark görülmedi $(p \geq 0,05)$ (Tablo $1,2)$.

Tablo 1. mTOR ve kan aminoasitler ortalama düzeyleri

\begin{tabular}{|c|c|c|c|}
\hline & Grup & Ortalama & |istatistik (p) \\
\hline \multirow{2}{*}{ Valin (Val) } & Hasta & $142,21 \pm 41,11$ & \multirow{2}{*}{0,624} \\
\hline & Kontrol & $147,15 \pm 55,49$ & \\
\hline \multirow{2}{*}{ Lösin (Leu) } & Hasta & $129,16 \pm 39,05$ & \multirow{2}{*}{0,957} \\
\hline & Kontrol & $128,6454,28$ & \\
\hline \multirow{2}{*}{ İzolösin (Ile) } & Hasta & $74,00 \pm 26,49$ & \multirow{2}{*}{0,244} \\
\hline & Kontrol & $67,00 \pm 31,38$ & \\
\hline \multirow{2}{*}{ Fenilalanin(Phe) } & Hasta & $64,47 \pm 20,88$ & \multirow{2}{*}{0,955} \\
\hline & Kontrol & $64,80 \pm 34,74$ & \\
\hline \multirow{2}{*}{ Triptofan (Trp) } & Hasta & $57,73 \pm 21,80$ & \multirow{2}{*}{0,574} \\
\hline & Kontrol & $60,87 \pm 31,47$ & \\
\hline \multirow{2}{*}{ Treonin (Thr) } & Hasta & $85,94 \pm 32,66$ & \multirow{2}{*}{0,793} \\
\hline & Kontrol & $88,12 \pm 46,69$ & \\
\hline \multirow{2}{*}{ Metiyonin (Met) } & Hasta & $32,53 \pm 13,40$ & \multirow{2}{*}{0,939} \\
\hline & Kontrol & $32,29 \pm 16,21$ & \\
\hline \multirow{2}{*}{ Lizin (Lys) } & Hasta & $152,57 \pm 60,25$ & \multirow{2}{*}{0,874} \\
\hline & Kontrol & $155,00 \pm 86,49$ & \\
\hline \multirow{2}{*}{ Histidin (His) } & Hasta & $96,71 \pm 44,35$ & \multirow{2}{*}{0,072} \\
\hline & Kontrol & $80,26 \pm 43,79$ & \\
\hline \multirow{2}{*}{ Glisin (Gly) } & Hasta & $135,39 \pm 110,96$ & \multirow{2}{*}{0,514} \\
\hline & Kontrol & $123,41 \pm 60,59$ & \\
\hline \multirow{2}{*}{ Prolin (Pro) } & Hasta & $197,15 \pm 70,05$ & \multirow{2}{*}{0,501} \\
\hline & Kontrol & $186,81 \pm 78,88$ & \\
\hline \multirow[b]{2}{*}{ Arjinin (Arg) } & Hasta & $19,08 \pm 9,46$ & \multirow[b]{2}{*}{0,044} \\
\hline & Kontrol & $22,82 \pm 8,36$ & \\
\hline \multirow{2}{*}{ Sistein (Cys) } & Hasta & $1,28 \pm 1,05$ & \multirow{2}{*}{0,220} \\
\hline & Kontrol & $1,52 \pm 0,71$ & \\
\hline \multirow{2}{*}{ Tirozin (Tyr) } & Hasta & $92,97 \pm 37,86$ & \multirow{2}{*}{0,865} \\
\hline & Kontrol & $94,42 \pm 44,4$ & \\
\hline \multirow{2}{*}{ Glutamin (Gln) } & Hasta & $239,58 \pm 130,15$ & \multirow{2}{*}{0,080} \\
\hline & Kontrol & $295,67 \pm 174,40$ & \\
\hline \multirow{2}{*}{ mTOR } & Hasta & $4,90 \pm 1,90$ & 0.558 \\
\hline & Kontrol & $4,67 \pm 1,51$ & ,, 530 \\
\hline
\end{tabular}

Tablo 2. mTOR proteini ile amino asit düzeyleri korelasyonu

\begin{tabular}{|c|c|c|c|c|c|c|c|c|c|c|c|c|c|c|c|c|}
\hline & & Val & Leu & Ille & Phe & Trp & Thr & Met & Lys & His & Gly & Pro & Arg & Cys & Tyr & Gln \\
\hline & $r$ &,- 043 & $3-020$ &,- 039 &, 004 & ,207 & ,203 & -056 &, 062 & ,204 &,- 027 &, 061 &,- 112 &, 046 & ,025 &,$- 137 \mid$ \\
\hline & $p$ &, 793 &, 901 &, 813 &, 981 &, 199 &, 209 &, 732 &, 705 &, 206 & 869 &, 709 & , 490 &, 776 &, 877 & , 400 \\
\hline
\end{tabular}

Ayrica amino asit parametreleri hasta ve kontrol grubunda yaşa göre kabul görülen referans aralıklarıyla değerlendi- rildi. Bu referans aralıklarına göre azalmış, normal ve artmış olarak sınıflandırıldı. Bu sınıflandırmaya göre yapıIan karşılaştırmalarda, Val için bakıldığında hasta grubunda 17 olguda $(\% 35,4)$ azalmıştı, 31 olguda $(\% 64,6)$ normaldi. Kontrol grubunda ise 15 olguda $(\% 31,9)$ azalmıştı, 32 olguda $(\% 68,1)$ normaldi. Bu sonuçlar iki grup arasında karşılaştııılığında istatistiksel olarak bir fark yoktu $(p=0,719)$.

Leu için bakıldığında hasta grubunda 1 olguda $(\% 2,1)$ azalmıştı, 43 olguda $(\% 89,6)$ normaldi, 4 olguda $(\% 8,3)$ artmıştı. Kontrol grubunda ise 2 olguda $(\% 4,3)$ azalmıştı, 42 olguda $(\% 89,4)$ normaldi, 3 olguda $(\% 6,4)$ artmıştı. Bu sonuçlar iki grup arasında karşılaştırıldığında istatistiksel olarak bir fark yoktu $(p=0,538)$.

\section{Tartışma}

Ağır beslenme yetersizliği önemli bir küresel sağlık sorunu olmaya devam etmektedir. Malnütrisyonun gelişmemiş ülkelerde çocukluk ölümlerine önemli bir etkisi olduğu bilinmektedir (7). Malnütrisyon ve beslenme problemlerinin hemen hemen tüm sistem ve organları doğrudan ya da dolaylı olarak etkilemesi ve günümüzde halen önemli bir sorun olması nedeniyle, büyüme ve gelişme üzerinde etkili olabilecek birtakım yeni parametreler ve belirteçler bulunabilir.

Plazma amino asitlerini hastalık riskini tanımlamak için metabolik bir alt grup olarak kullanma potansiyeli gösterilmiştir $(8,9)$ ve düşük aminoasit seviyelerinin protein yetersiz beslenmeye bir belirteç olabileceğine dair kanıtlar bulunmaktadır. Bu nedenle bu çalışmada, büyüme ve gelişme geriliği olan hastalarda aminoasit ve mTOR protein düzeylerini inceledik.

Şu ana kadar fazla araştırımamış olmasına rağmen, yetersiz beslenme veya yetersiz protein alımının plazma serbest amino asit profillerini önemli ölçüde etkilediği gösterilmiştir (10-12).

Imaizumi ve ark. (13), Low-EAA'lı denekler ile protein enerji malnütrisyonu olan hastalarda aminoasit seviyelerinde düşüklük tespit etmişlerdir. Özellikle esansiyel amino asit seviyesi düşük olanların anemi, kardivasküler hastalık ve bulaşıcı hastalıklarla ilişkili olduğunu göstermişler (13). Amino asitlerin ve özellikle esansiyel amino asitlerin düzeyi, kwashiorkorlularda düşük olarak bulunmuş ve bu daha önce kwashiorkorlularda gösterilen amino asitlerin metabolik akısındaki farkılıklar ile ilişkili olabilir $(14,15)$. Bu çalışmada vakaların amino asit düzeylerine bakıldığında; Arg, hasta grubunda anlamlı olarak düşük bulunurken, diğer amino asit düzeylerinde beklenenin aksine istatistiksel olarak anlamlı bir fark görülmedi. Ancak Val, Trp, Tirozin, lys, Cys, Hys, treonin, glutamin aminoasit seviyelerinde kontrol grubuna göre istatistiksel olarak anlamlı olmayan bir şekilde düşük olduğu görüldü. Bunun, çalışmamızdaki vakaların nispeten daha stabil, polikliniğe ayaktan başvuran, genel durumları düşkün 
olmayan ve hafif malnütrisyonu olan vakalar olmasına bağladık. Bazı çalışmalar da persentil eğrilerini 3.persentilin altında olmasını malnütrisyonu belirlemek için yeterli görmemektedir. Lee JL ve ark. (16) ile Komai S ve ark. (17) vücut kitle İndeksi, albümin veya prealbümin gibi yetersiz beslenme için mevcut belirteçlerin aşırı açlığa kadar protein kalorili malnütrisyona sahip bireylerin belirlenmesinde başarısız olduğu bildirilmektedir (16-17). Bütün bitkiler, proteinlerde yaygın olarak bulunan 20 tip amino asidi sentezleyebilse de hayvanların 9 temel amino asit almaları gerekir: histidin, izolösin, lösin, lisin, metiyonin, fenilalanin, treonin, triptofan ve gıda olarak valin. Bireyin fizyolojik ve patolojik koşullarına bağlı olarak, bu 9 amino aside ek olarak, vücut protein homeostazını korumak için arginin gerekebilir ve yarı esansiyel bir amino asit olarak adlandırılır. Yetersiz protein alımı, plazmada düşük konsantrasyonlarda esansiyel ve yarı esansiyel amino asitleri tetikleyebilir $(11,12)$. Önemli konulardan biri, genellikle sağıklı kişilerde plazmada mutlak konsantrasyonlara dayanan klinik referans aralıklarını pekiştirmektir (9). Referans aralıkları ile karşılaştırarak, belirli metabolitlerin konsantrasyonlarının düşük, normal veya yüksek olduğu teşhis edilebilir. Bu çalışmada Val, Trp, Tirozin, lys, Cys, Hys, treonin, glutamin aminoasit seviyelerinde kontrol grubuna göre görece düşük iken, arginin anlamlı olarak düşük bulundu. Muhtemelen vakaların malnütrisyon süresi uzadığında plazma amino asit seviyelerinde daha yaygın ve daha ciddi düşüklük tespit edilecektir. Metionin, fenilalanin ve lösin normal, prolin, histidin, Isolösin, glisin ise yüksek görüldü. Bu aminoasitlerin daha yüksek olarak tespit edilmiş olması, muhtemelen daha iyi beslenme durumunu yansıtmaz, ancak kronik metabolik düzensizlikleri gösterebilir.

Lösin ve esansiyel amino asitlerin plazmada önemi iyi bildirilmiştir ve lösin, öncelikle Rapamisinin Memeli Hedefi (mTOR) sinyal yolunu aktive ederek protein sentezini uyarmaktadır. Kas protein sentezinin uyarıması temel olarak esansiyel amino asitlere bağlıdır, çünkü sadece esansiyel amino asitler alındığında net protein sentezi vardır (18). Kas proteini sentezi, esansiyel olmayan amino asitler toplam bir amino asit karışımından çıkarıldığında benzer şekilde uyarıı (18). Lösinle zenginleştirilmiş esansiyel bir amino asit besin çözeltisinin yutulması, insan iskelet kası içindeki mTOR sinyal yolunu ve protein sentezini hızla aktive eder (19). Ayrıca, egzersiz sonrası lösine zenginleştirilmiş besinler alındığında, mTOR sinyalleri ve kas protein sentezi arttırıır (20-22). Bu çalışmadaki olguların mTOR protein düzeylerine bakıldığında hasta grubu kontrol grubu arasında anlamlı bir fark tespit edilemedi. Bunun plazma serbest amino asit seviyelerinde ciddi bir değişim olmamasından ve lösin düzeyinin normal olarak bulunmasından kaynaklandığını düşündük.

Son zamanlarda, biriken kanitlar, plazma serbest amino asit konsantrasyonlarının; dallı zincirli amino asitlerin ve aromatik amino asitlerin yükselmeleri, viseral obezite (23), insülin direnci (24-26) ve gelecekteki diyabet ve kardiyovasküler hastalıkların gelişimi gibi aşırı beslenmeden kaynaklanan sonuçlarla ilişkilendirmiştir (27-29). Yetersiz protein alımı nedeniyle plazmada esansiyel ve yarı esansiyel amino asit konsantrasyonlarındaki azalma, protein yetersiz beslenmesinin başlattığı klinik sorunları tetikleyebilir ve dolayısıyla serbest plazma amino asitleri yetersiz beslenme ve hastalık riskleri açısından bir kişinin sağığı için potansiyel bir belirteçtir.

Bu çalışmadaki kısıtlamalardan ilki, metabolit değişikliklerinin spesifik fizyolojik süreçlerle ilişkisinin tespit edilememesidir. Normal bazal koşullarda, bir metabolit değişikliği belirli bir fizyolojik durumu gösterebilir, ancak malnütrisyonlu çocuklarda metabolik olarak bozulmuş bir popülasyonda farklı bir marker ile de ilişkilendirilebilir. Ikinci olarak, incelenen hastaların yedikleri son yemekle ilgili olarak kan alımlarının zamanlaması hakkında belirli veriler yoktu ve bu da metabolik profillere değişkenlik katabilir. Ayrıca, daha uzun bir takip süresine sahip olmak, metabolik değişikliklerin süresinin belirlenmesine yardımcı olacaktır. Son olarak, bu çalışmada malnütrisyon sınıflaması yapılamadığından değerlendirme sınırlı olacaktır. Ağır derecede malnütre olan olguların sonuçları anlamlı iken hafif ve komplike olmayan çocukların metabolik profili, kontrol grubuna benzer olabilir.

Sonuç olarak, plazma amino asit konsantrasyonlarını belirli fizyolojik ve hastalık durumları için belirteçler olarak kullanılabilir. Düşük aminoasit seviyelerinin protein yetersiz beslenmesinde erken bir belirteç olabileceğine dair kanıtlar bulunmaktadır. Yetersiz beslenme, metabolitlerdeki değişiklikler ve fizyolojik sonuçlarla ilgili yapılacak araştırmalara intiyaç vardır. Kötü beslenmeyi, amino asitlerdeki azalmayı ve fizyolojik sonuçları ilişkilendirmek için yapılacak ileri araştırmalar, olumsuz sonuçları önlemek veya düzeltmek için erken beslenme müdahalelerinin yapıImasını önemli kılacaktır.

Etik Onam: Çalışma için Harran Üniversitesi Tıp Fakültesi Etik Kurulu'ndan etik onam alındı (09/11/2017 tarih ve 11nolu oturum 04 nolu karar).

\section{Kaynaklar}

1. Organization WH. Indicators for assessing infant and young child feeding practices: part 2: measurement. 2010.

2. Gómez F, Galvan RR, Frenk S, Muñoz JC, Chávez R, Vazquez J. Mortality in second and third degree malnutrition. 1956. Bulletin of the World Health Organization. 2000;78(10):1275.

3. Mishra S, Bastola S, Jha B. Biochemical nutritional indicators in children with protein energy malnutrition attending Kanti Children Hospital, Kathmandu, Nepal. Kathmandu University Medical Journal. 2009;7(2):129-34.

4. Arıkan D, Alp H. Erzurum il merkezindeki sağlık ocaklarına kayıtlı 024 aylık çocuklarda beslenme durumu, malnütrisyon prevalansı ve onu etkileyen faktörler: doktora tezi: Atatürk Üniversitesi; 1995.

5. Lafyatis R. Targeting fibrosis in systemic sclerosis. Endocrine, Metabolic \& Immune Disorders-Drug Targets (Formerly Current Drug 
Targets-Immune, Endocrine \& Metabolic Disorders). 2006;6(4):395400.

6. Klionsky DJ. The molecular machinery of autophagy: unanswered questions. Journal of cell science. 2005;118(1):7-18.

7. Black RE, Victora CG, Walker SP, Bhutta ZA, Christian P, De Onis $M$, et al. Maternal and child undernutrition and overweight in lowincome and middle-income countries. The lancet. 2013;382(9890):427-51.

8. Noguchi $Y$, Zhang Q-W, Sugimoto T, Furuhata Y, Sakai R, Mori M, et al. Network analysis of plasma and tissue amino acids and the generation of an amino index for potential diagnostic use. The American Journal of Clinical Nutrition. 2006;83(2):513S-9S.

9. Borges A, J Saavedra M, Simoes M. Insights on antimicrobial resistance, biofilms and the use of phytochemicals as new antimicrobial agents. Current medicinal chemistry. 2015;22(21):2590-614.

10. Polge A, Bancel E, Strubel HBD, Peray SPP, Carlet C, DE Bornier $B M$. Plasma amino acid concentrations in elderly patients with protein energy malnutrition. Age and ageing. 1997;26(6):457-62.

11. Fujita $Y$, Yoshimura $Y$, Inoue G. Effect of low-protein diets on free amino acids in plasma of young men: effect of protein quality with maintenance or excess energy intake. Journal of nutritional science and vitaminology. 1978;24(3):297-309.

12. Fujita $Y$, Yamamoto T, Rikimaru T, Inoue G. Effect of low protein diets on free amino acids in plasma of young men: effect of wheat gluten diet. Journal of nutritional science and vitaminology. 1979;25(5):427-39.

13. Yamakado M. "AminoIndex Technology" for Lifestyle-related Disease Risk Screening. Ningen Dock International. 2018;5(1):3-14.

14. Jahoor F, Badaloo A, Reid M, Forrester T. Protein kinetic differences between children with edematous and nonedematous severe childhood undernutrition in the fed and postabsorptive states. The American journal of clinical nutrition. 2005;82(4):792-800.

15. Manary MJ, Broadhead RL, Yarasheski KE. Whole-body protein kinetics in marasmus and kwashiorkor during acute infection. The American journal of clinical nutrition. 1998;67(6):1205-9.

16. Lee JL, Oh ES, Lee RW, Finucane TE. Serum albumin and prealbumin in calorically restricted, nondiseased individuals: a systematic review. The American journal of medicine. 2015;128(9):1023. e1-. e22.

17. Komai S, Watanabe $Y$, Fujiwara $Y$, Kim H, Edahiro A, Kawai $H$, et al. Association between the nutritional status and the severity of sarcopenia among community-dwelling elderly Japanese people. Nihon Ronen Igakkai Zasshi Japanese Journal of Geriatrics. 2016;53(4):38795.

18. Volpi E, Kobayashi H, Sheffield-Moore M, Mittendorfer B, Wolfe RR. Essential amino acids are primarily responsible for the amino acid stimulation of muscle protein anabolism in healthy elderly adults. The American journal of clinical nutrition. 2003;78(2):250-8.

19. Drummond MJ, Rasmussen BB. Leucine-enriched nutrients and the regulation of mTOR signalling and human skeletal muscle protein synthesis. Current opinion in clinical nutrition and metabolic care. 2008;11(3):222.

20. Dreyer HC, Drummond MJ, Pennings B, Fujita S, Glynn EL, Chinkes DL, et al. Leucine-enriched essential amino acid and carbohydrate ingestion following resistance exercise enhances mTOR signaling and protein synthesis in human muscle. American Journal of Physiology-Endocrinology And Metabolism. 2008;294(2):E392-E400.

21. Kim HK, Suzuki T, Saito K, Yoshida $H$, Kobayashi $H$, Kato $H$, et al. Effects of exercise and amino acid supplementation on body composition and physical function in community-dwelling elderly Japanese sarcopenic women: a randomized controlled trial. Journal of the American Geriatrics Society. 2012;60(1):16-23.

22. Kim H, Suzuki T, Saito K, Kojima N, Hosoi E, Yoshida H. Longterm effects of exercise and amino acid supplementation on muscle mass, physical function and falls in community-dwelling elderly $\mathrm{J}$ apanese sarcopenic women: A 4-year follow-up study. Geriatrics \& gerontology international. 2016;16(2):175-81.

23. Yamakado M, Tanaka T, Nagao K, Ishizaka $Y$, Mitushima T, Tani $\mathrm{M}$, et al. Plasma amino acid profile is associated with visceral fat accumulation in obese Japanese subjects. Clinical Obesity. 2012;2(12):29-40.

24. Tai E, Tan M, Stevens R, Low Y, Muehlbauer M, Goh D, et al. Insulin resistance is associated with a metabolic profile of altered protein metabolism in Chinese and Asian-Indian men. Diabetologia. 2010;53(4):757-67.

25. Würtz $P$, Mäkinen V-P, Soininen $P$, Kangas AJ, Tukiainen $T$, Kettunen J, et al. Metabolic signatures of insulin resistance in 7,098 young adults. Diabetes. 2012;61(6):1372-80.

26. Nakamura $H$, Jinzu H, Nagao K, Noguchi $Y$, Shimba N, Miyano $H$, et al. Plasma amino acid profiles are associated with insulin, C-peptide and adiponectin levels in type 2 diabetic patients. Nutrition \& diabetes. 2014;4(9):e133-e.

27. Wang TJ, Larson MG, Vasan RS, Cheng S, Rhee EP, McCabe E, et al. Metabolite profiles and the risk of developing diabetes. Nature medicine. 2011;17(4):448-53.

28. Yamakado M, Nagao K, Imaizumi A, Tani M, Toda A, Tanaka T, et al. Plasma free amino acid profiles predict four-year risk of developing diabetes, metabolic syndrome, dyslipidemia, and hypertension in Japanese population. Scientific reports. 2015;5:11918.

29. Nagao K, Yamakado M. The role of amino acid profiles in diabetes risk assessment. Current opinion in clinical nutrition and metabolic care. 2016;19(5):328-35. 